$s^{2}$

\title{
RADIATION EFFECTS TESTING \\ AT THE LOS ALAMOS \\ GODIVA II FACILITY
}

LJ Zipprich

Compiler

\section{R E P R I N T}




\section{DISCLAIMER}

This report was prepared as an account of work sponsored by an agency of the United States Government. Neither the United States Government nor any agency Thereof, nor any of their employees, makes any warranty, express or implied, or assumes any legal liability or responsibility for the accuracy, completeness, or usefulness of any information, apparatus, product, or process disclosed, or represents that its use would not infringe privately owned rights. Reference herein to any specific commercial product, process, or service by trade name, trademark, manufacturer, or otherwise does not necessarily constitute or imply its endorsement, recommendation, or favoring by the United States Government or any agency thereof. The views and opinions of authors expressed herein do not necessarily state or reflect those of the United States Government or any agency thereof. 


\section{DISCLAIMER}

Portions of this document may be illegible in electronic image products. Images are produced from the best available original document. 
Revision of an Informal Memorandum

\title{
GODIVA II - ITS AVAILABILITY AND SUITABILITY FOR RADIATION EFFECTS TESTS
}

\author{
Compiled by
}

W. J. Buckalew

LEGAL NOT ICE

This report was prepared as an account of Government sponsored work. Neither the United States, nor the Commission, nor any person acting on behalf of the Commission:

A. Makes any warranty or representation, express or implied, with respect to the accuracy, completeness, or usefulness of the information contained in this report, or that the use of any information, apparatus, method, or process disclosed in this report may not infringe privately owned rights; or

B. Assumes any liabilities with respect to the use of, or for damages resulting from the use of any information, apparatus, method, or process disclosed in this report.

As used in the above, "person acting on behalf of the Commission" includes any employee or contractor of the Commission to the extent that such employee or contractor prepares, handles or distributes, or provides access to, any information pursuant to his employment or contract with the Commission.

Printed in USA. Price $\$ 0.75$. Available from the Office of Techuical Services, Dcpartment of Commerce, Washington 25, D. C. 
SCR-76

RADIATION EFFECTS ON MATERIALS

TID-4500 (14th Ed.)

\section{SANDIA CORPORATION REPRINT}

RADIATION FFFECTS TESTING AT. THE LOS ALAMOS GODIVA II FACILITY

compiled by

L. J. Zipprich

April 1959 
TABLE OF CONTENTS

Page

I. Introduction . . . 3

II. Test Program Requirements.

III. Facilities and Services Provided by LASL _ . 6

IV. Description and Characteristics of Godiva II . $\quad 7$

LIST OF ILLUSTRATIONS

Figure

1. Godiva II Reactor - Side View : $\quad 10$

2. Godiva II - Side View Sketch 11

3. Godiva II - Top View 12

4. Godiva III - Top View Siketch 13

5. Godiva IT Critical Assembly 14

6. Typical Experimental Setup - View of Godiva II 15

7. Kiva II and Control Room - Area Map 16

8. Kiva II - Godiva II and Facilities Layout 17

9. Spectrum Comparison - Godiva I Leakage Spectrum and
$\mathrm{U}_{235}$ Fission Spectrum

10. Typical Godiva II Fission Pulse Trace 19 


\section{RADIATION EFFECTS TESTING AT THE LOS ALAMOS GODIVA II FACILITY}

\section{Introduction}

\section{A. Agreement for DOD Use of the Godiva II Facility}

The Los Alamos Scientific Laboratory (LASL), recognizing the unique nuclear environment offered by Godiva II radiation bursts, has agreed to make this facility available without charge to DOD contractors on a general schedule of 2 days each month for the performance of qualified radiation effects tests. Since radiation effects testing is an endeavor outside the general field of interest of Department N-2 at LASL, Sandia Corporation Division. 1626 has been authorized to coordinate this use of the facility. DOD contractors may request timc at the Godiva II facility to conducl radiation effects tests of the following types:

1. Basic studies on material changes and peculiar phenomena resulting from exposure to a nuclear burst.

2. Engineering tests on components and circuits of weapon or defense systems, or studies supporting development of such systems.

3. Study or calibration of dosimetry techniques and devices designed for nuclear burst measurements.

More requests for testing space at Godiva II bursts are received than can be adequately accommodated. Duplication of tests should be avoided, and test results must be made readily available to insure a maximum over-all benefit from the time available. 


\section{Test Program Requirements}

\section{A. Planning Phase}

1. Sandia Corporation, Division 1626, will assign reservations to qualified requesters. Additional tests are scheduled concurrently whenever possible, subject to the approval of the agency having the farility reserved.

2. Tests must be designed to be "self-sufficient"; i.e., LASL provides a nuclear environment and a nominal amount of power and supporting facilities; additional equipment must be provided by the experimenter.

3. A preliminary test outline containing illul mation on the type of test planned and requirements for space, power, control leads, etc., should accompany the request for space in order to facilitate scheduling.

4. A more detailed test outline containing the following information must be provided Sandia Corporation at least 3 weeks prior to the test:

a. A brief description of the experiment to be conducted.

b. The approximate dimensions and a description of the test stand and samples as they will be positioned at the Godiva II facility.

c. Power and signal lead requirements:

d. Namies of personnel to be at J.ASL to conduct the test (this number should be kept to a minimum--it is suggested that not more than two persons per project be at the Godiva II facility during the tests).

5. Security clearance requests should be submitted to LASL according to the rules outlined for use of AEC Form 277 or appropriate equivalent clearance request.

a. Clearance requests should indicate that the purpose of the visit is to perform radiation effects tests using Godiva II in accordance with the agreement for DOD use of the facility.

b. Clearance requests for access to the Pajarito Site will ordinarily be limited to the test dates plus the 2 working days before and 2 working days after.

6. Equipment shipped to LASL should:

a. Contain a manifest identifying the contents; and to avoid opening by LASL receiving personnel, should be clearly marked, "Shipment should be handled in accordance with BQ-29." 
b. Include a government bill of lading for shipment to and from LASL;

or if shipped by public carrier, contain instructions for return shipment C. O.D.

7. Hotel reservations may be made by contacting The Lodge, Los Alamos, New Mexico. Reservation requests should be made at least 2 weeks prior to arrival.

\section{B. Testing Phase}

1. Tests at the Godiva II are to be conducted with a minimum of interference to normal LASL functions. The number of visiting personnel should be kept to the minimum required to conduct the planned tests. In any case, the total number of visitors must not exceed 20; each participating agency will, therefore, be limited according to the number of tests planned for a particular date.

2. Agency personnel are expected to conform to Los Alamos N-2 Group rules of safe operating procedures which apply to the Godiva facility (such rules will be available in mimeograph form at the Pajarito Site).

3. Health Physics rules and instructions for the Pajarito Site must be strictly observed. In many cases, visiting personnel may find it convenient to arrive with a written record of their radiation exposure for the year and authorization specifying the maximum radiation dose which they may receive during the 2 daye of operalion. Otherwise all visilur's will be restricted from the Kiva after the normal weekly tolerance dose of $0.3 \mathrm{rad}$ is received. (Since pocket dosimeter readings usually indicate approximately one-half the dose shown by film badges, a pocket dosimeter reading of $0.15 \mathrm{rad}$ is taken as an indication that the weekly tole rance has been reached.)

4. The agency holding a reservation for Godiva II time is responsible for the positioning of tests around the Godiva II, use of supporting facilities, and the schedule of "bursts" to be fired. The LASL operator of Godiva II will make any decisions affecting the operation or safety of Godiva II itself.

\section{Publication of Information}

1. Reports on testing technique and radiation effects information obtained through tests at Godiva II must be made available to LASL N-2 Division, Sandia Corporation Division 1626 , and interested DOD agencies upon request as soon as possible after the test is conducled.

2. Reports should be kept unclassified, if possible, and be issued in a form to facilitate external distribution. 
3. Sandia Corporation Division 1626 will serve as a gathering agency for reports and information on Godiva II tests and testing technique. Inquiries and comments are invited, and information concerning Godiva II and tests at the facility will be supplied to the extent possible.

4. Effective use of time at the Godiva II facility and promptness in making information obtained generally available will be considerations in scheduling requests for further tests at the facility.

III. Facilities and Services Provided hy LASL

A. Radiation Effects Test Scheduling

Los Alamos has agreed to allow use of the Godiva II for radiation effects test-ing on a basis of 2 days per month, plus $1 / 2$ day immediately prior to the "burst days" for test setup.

The days the facility is available each month will be governed by LASL requirements; however, radiation effects tests will generally be scheduled on the last Thursday and Friday of the month unless another date is mutually agreed upon.

\section{B. Reactor Operator and Health Physics}

Los Alamos N-2 will provide an experienced reactor operator to check experimental setups and operate Codiva IT; LASL Health Physics will monitor operations to assure that visiting personnel will not be exposed to excessive nuclear radiation. (LASL film badges will be issued to all visitors and must be worn according to LASL instructions.)

C. Power and Signal Leads

Los Alamos will provide power and signal leads as follows:

1. Power at the reactor building (Kiva II) (outlet box located outside SE corner - see Figure 8)

Outlets

1 ea 220 volts AC, 3 -phase, 60 amp/outlet

2 ea 220 volts $A C, 1$-phase, $30 \mathrm{amp} /$ outlet $\} 60 \mathrm{amp}$ tutal

6 ea 110 volts AC, 1 -phase, $30 \mathrm{amp} /$ duplex $-60 \mathrm{amp}$ total 


\section{Receptacle type}

220 volts AC, 3-phase: Russell and Stoll Co., New York, N. Y., 2057 B, 4-wire, 4-pole, 60 amp

220 volts AC, 1-phase: Crouse-Hinds Co., Syracuse, N. Y., "Arktite," AR 337, 3-wire, 3-pole, 30 amp

110 volts AC, 1 -phase: Polarized 3 -pole, parallel blade.

2. Power. at the control room (behind racks)

110 volts AC, 1 -phase - 15 amp/outlet strip - 30 amp total

3. Signal leads - control room to Kiva II

2 ea $R G-22 / U$

2 ea RG-11/U terminated on patch panels with Amphenol SO-239 connectors. 2 ea $R G-63 / U$ )

20 ea No. 16 conductors - terminated on Curtis Blocks, compatible with lugs accommodating 10-32 screws.

\section{Godiva II Burst Characteristics}

1. Los Alamos will instrument the Godiva II so that the number of fissions resulting from a given burst will he known.

2. Los Alamos will make available to Sandia Corporation pertinent information (leakage spectrum charactcristics, position, modification, etc.) concerning Godiva II so that this information can be transmitted to organizations participating in Godiva II tests.

\section{Description and Characteristics of Godiva II*}

\section{A. History}

The production of self-limiting fission bursts initiated by a single large reactivity change was first demonstrated at the Los Alamos Scientific Laboratory with the bare spherical uranium metal critical assembly, "Lady Godiva, " or Godiva I, in 1953. Following completion of a program to determine properties of these bursts as functions of excess reactivity, there was an increasing demand for the use of Godiva I as an experimental tool in neutron pulse irradiation investigations. As a result, this experimental critical assembly was pressed into service as a fission burst facility and produced a total of approximately 1000 bursts before its retirement following an accidentally intense burst. A large backlog of experimental programs

*Wimett, T. F., and Orndoff, J. D. , Applications of Godiva II Neutron Pulses, Los Alamos Scientific Laboratory, 1958. 
necessitated the design and construction of Godiva II, which is similar to Godiva I except for differences in geometry arising from different functional requirements; Godiva II was designed specifically for the reliable production of super-promptcritical fission bursts while its predecessor was not.

\section{B. Construction}

Figure 1 is a photograph of Godiva II, showing the three-legged aluminum supporting structure which houses relay interlocks, pneumatic actuating devices, and local controls. Electrical control rod drives, including selsyns for transmitting rod positiun information to the remote control point, are visible on top of the tripod arrangement. Above these and inside a 9-inch-diameter wlre cagc is the nickelcoated active material, with configuration details as shown in Figure 5 . The major section is a right circular cylinder, approximately 7 inches in diameter by $5-1 / 2$ inches high, with a spherically shaped top. The cylinder is solid with the exception of four cavities opening at the bottom surface. A coaxial cylindrical cavity accom-

modates the "safety block" which is a solid cylinder and is shown in its "scrammed" position. Because reliable shutdown depends largely on the easy withdrawal of this safety block, a clearance of 0.06 inch is provided between its surface and the cavity to prevent jamming. Two control rods (2.3 dollars reactivity control) and a burst rod also enter the main section from the bottom. Both the main section and the safety block are mounted on 3/8-inch steel plates by means of uranium bolts; the plates are supported by vertical steel rods. Steel rods are threaded into the uranium control rods and burst rod to connect them through guides to actrating mechanisms--screws driven by electric motors for the control rods and a pneumatic cylinder for the burst rod. Pneumatic cylinders are also used to position the safety block and a $\mathrm{Pu}-\mathrm{Be}$ neutron source which can be raised from a remote position to a position 2 inches from the assembly surface. The total mass of enriched uranium $\left(\sim 93.2\right.$ percent $\left.U_{235}\right)$ is approximately $57.7 \mathrm{~kg}$. Operation of assembly machinery is performed entirely by remote control at a distance of about $1 / 4$ mile to ensure personnel safety.

\section{Burst Generation}

Under controlled conditions, a fission burst is generated by the sudden assembly of a supercritical configuration provided the act of assembly is completed before buildup of an appreciable neutron population. For predictable yields, it is also necessary that the excess reactivity of the final configuration be known to considerable accuracy. The procedure followed on Godiva II, which is consistent with 
these requirements, is first, to make an assembly with the burst rod retracted and the neutron source in position near the active material. The control rods are adjusted for steady power at some arbitrary low level, thus establishing a "delayed critical" configuration. Next, the safety block and the neutron source are retracted leaving the control rods in position, and the neutron population is allowed to decay. Upon reinserting the safety block and then inserting the burst rod (its out-position is chosen by previous calibration; insertion involves shifting from the out-position to $\sim 0.015$ inch of seating), a known final reactivity in the vicinity of prompt critical is attained.

The prompt fission burst is automatically limited by thermal expansion, but there persists a residual power level sustained by delayed neutron activity, as discussed in the next section. Because this residual level produces a temperature rise of $\sim 100^{\circ} \mathrm{C}$ per second, it is desirable to scram the assembly as rapidly as possible. For this purpose, a special "fast-scram" system was devised by which a radiation-level trigger pulse closes a solenoid air valve and applies pressure to the air piston which withdraws the safety block. Scram time achieved in this way is $\sim 0.04$ second. For safety, there are additional standard independent scram circuits connected to radiation monitors.

\section{Yield Description}

1. The Godiva II is designed to have a standardized yield of $10^{16}$ fissions per burst at a peak fission rate of about $10^{20}$ fissions per second.

2. There are approximately 1.4 leakage neutrons per fission, or correspondingly $1.4 \times 10^{16}$ leakage neutrons per burst at a peak rate of $1.4 \times 10^{20}$ leakage neutrons per second.

3. The neutron pulse is approximately 80 microseconds wide at half height.

4. The leakage spectrum is similar (Figure 9) to the fission spectrum of $\mathrm{U}_{235}$ but peaks at approximately $0.4 \mathrm{mev}$. The primary spectrum has negligible thermal and epithermal neutrons, but at distances beyond a few feet from the Godiva such neutrons become significant as a result of scattering from the Kiva walls. 


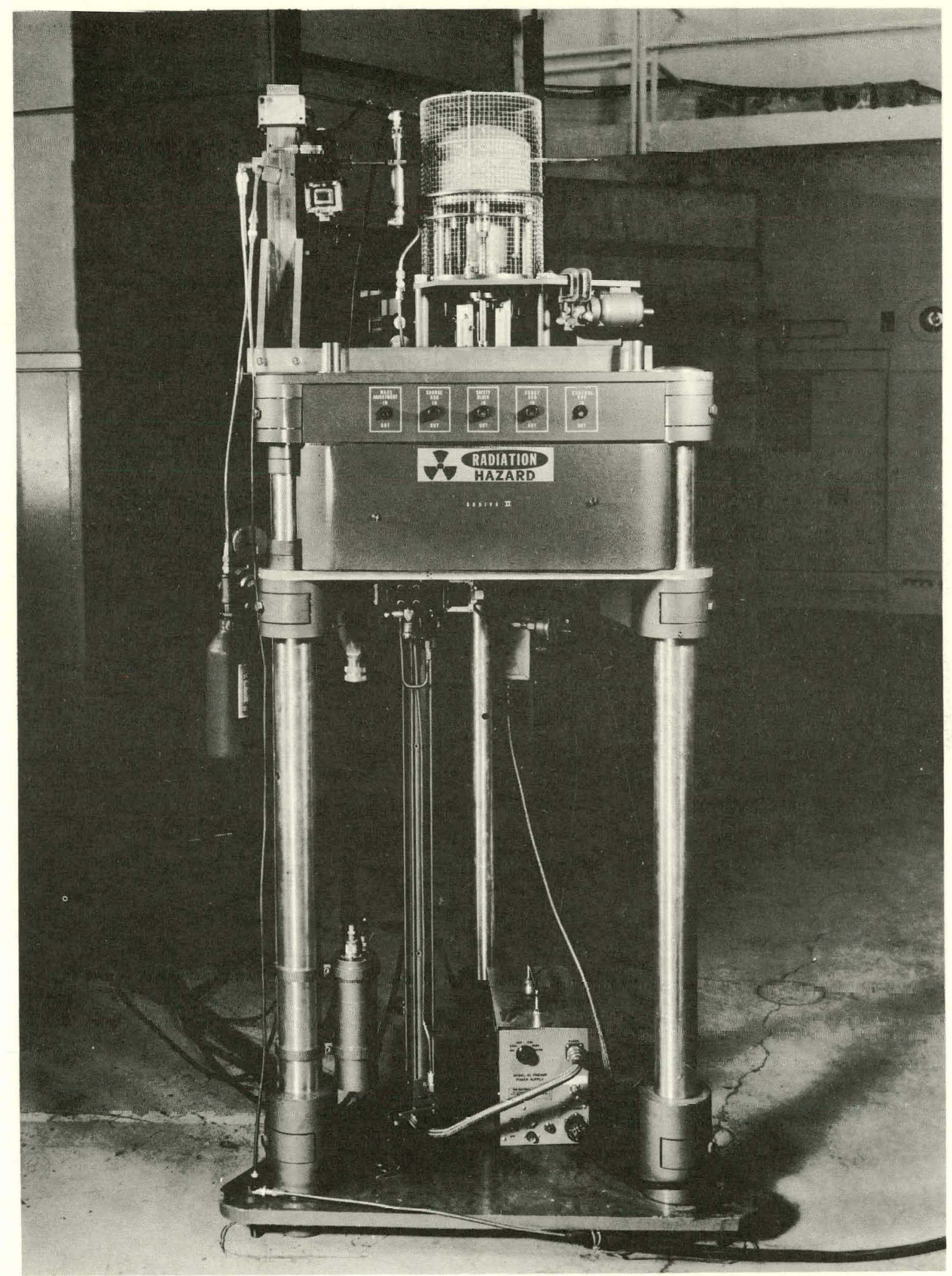

Figure 1. Godiva II Reactor - Side View 


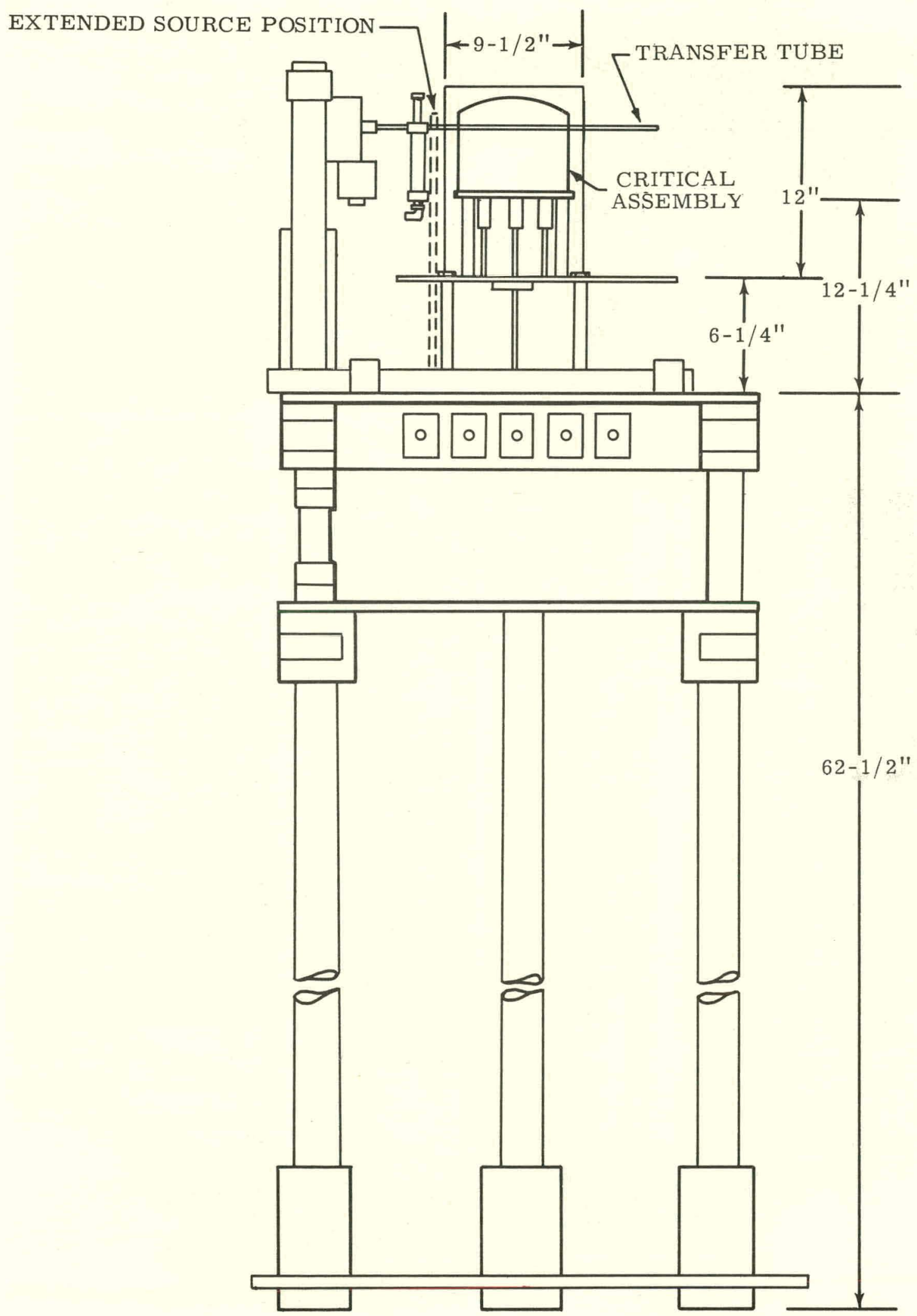

Figure 2. Godiva II - Side View Sketch 


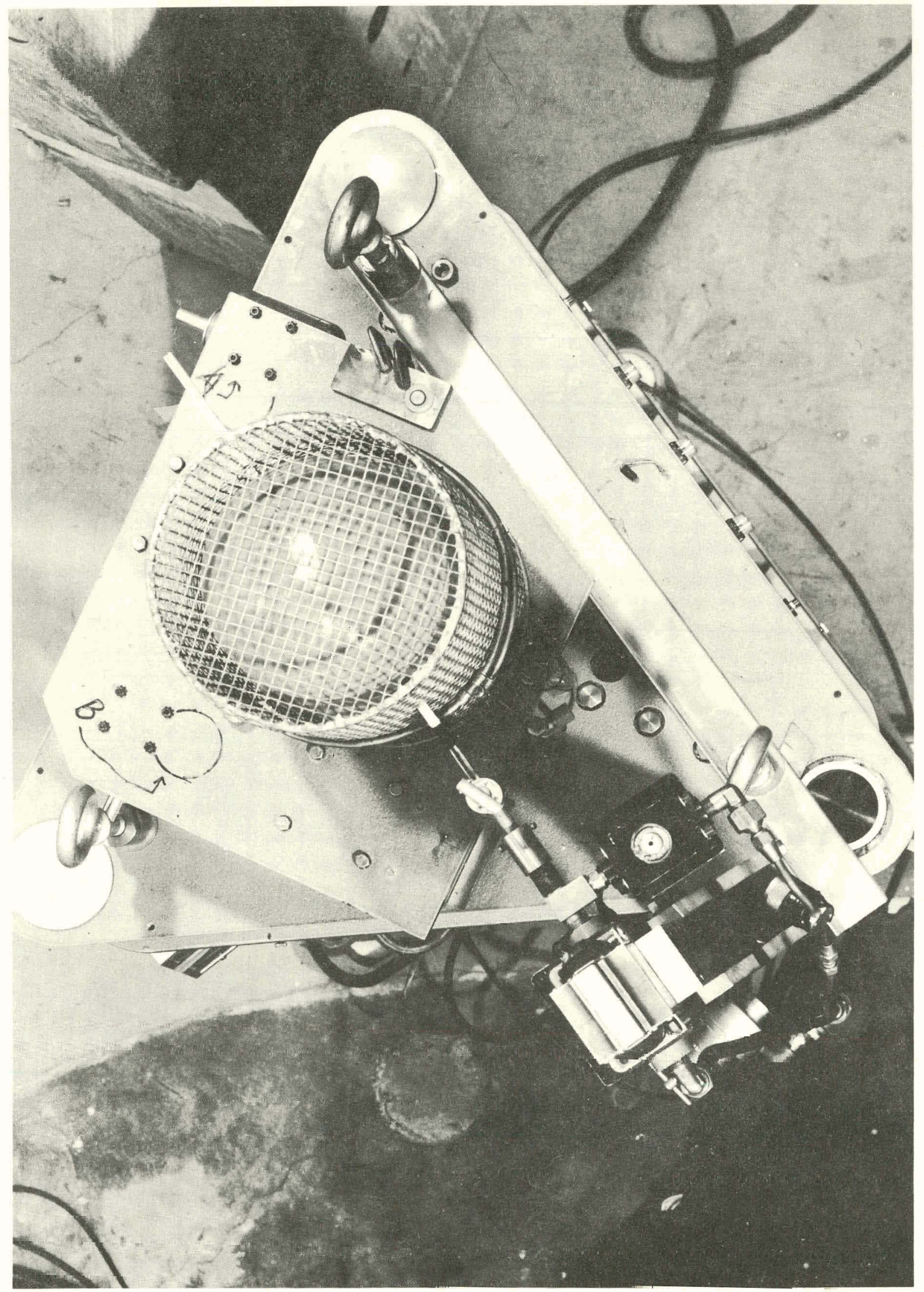

Figure 3. Godiva II - Top View 


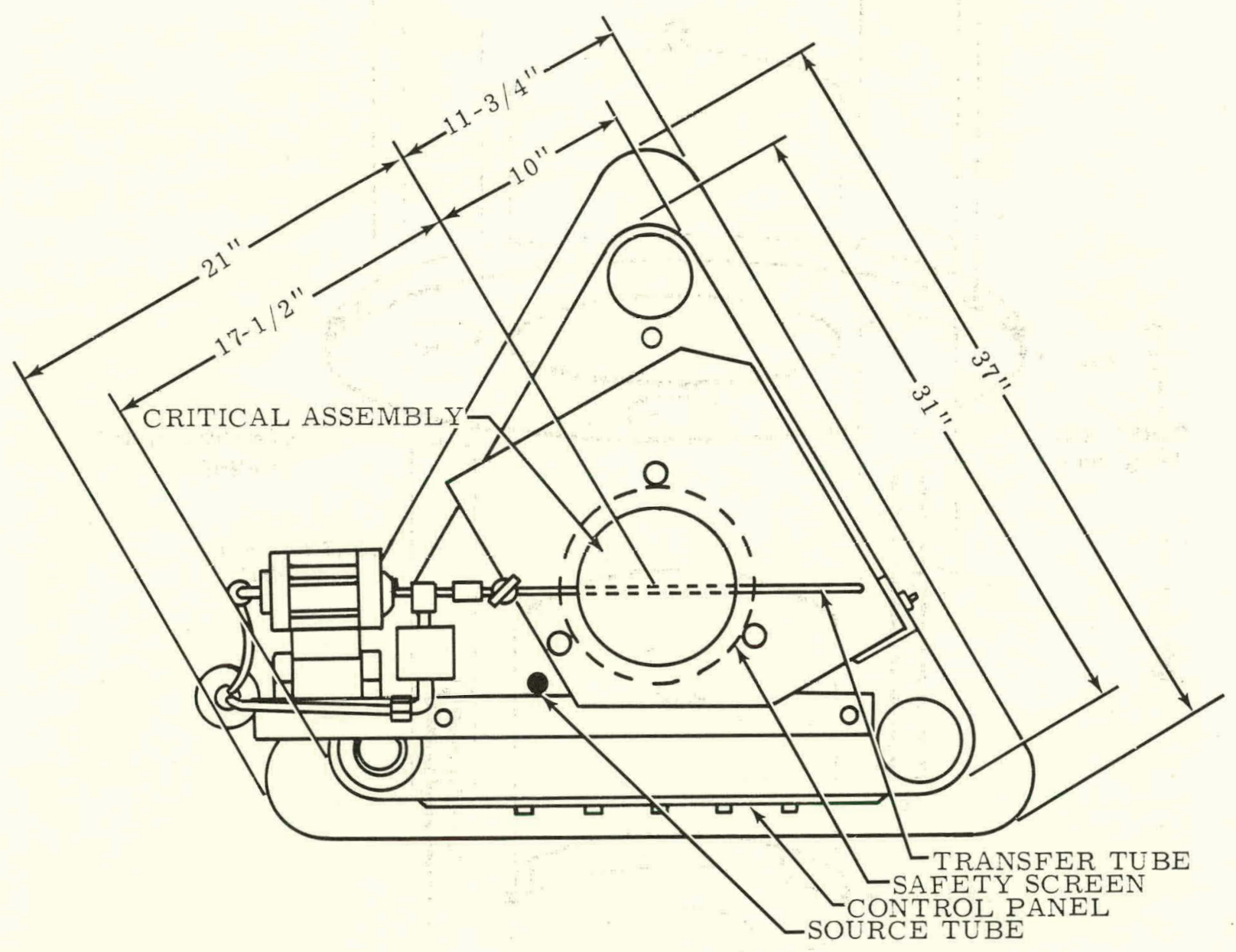

Figure 4. Godiva II - Top View Sketch 


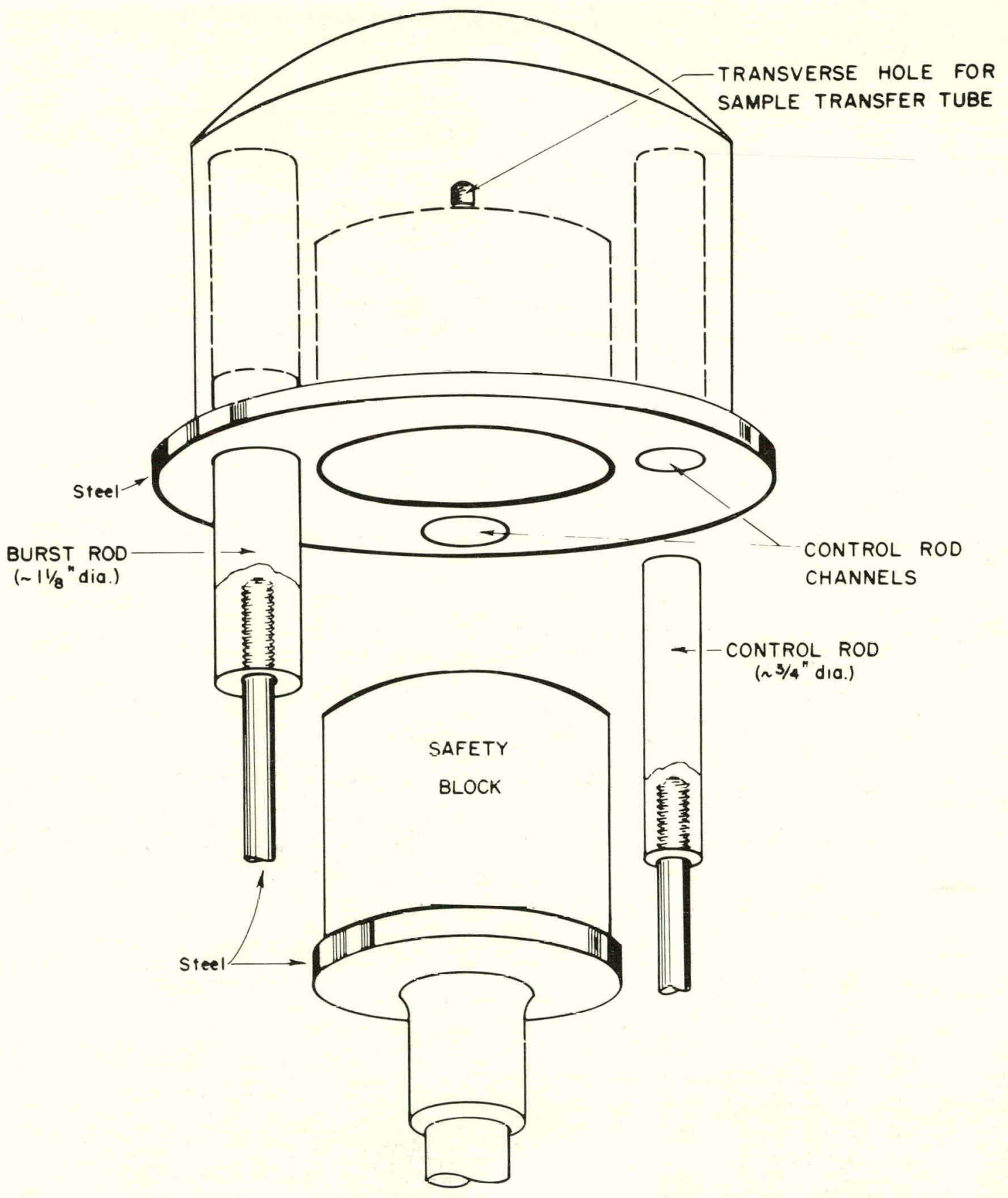

Figure 5. Godiva II Critical Assembly 


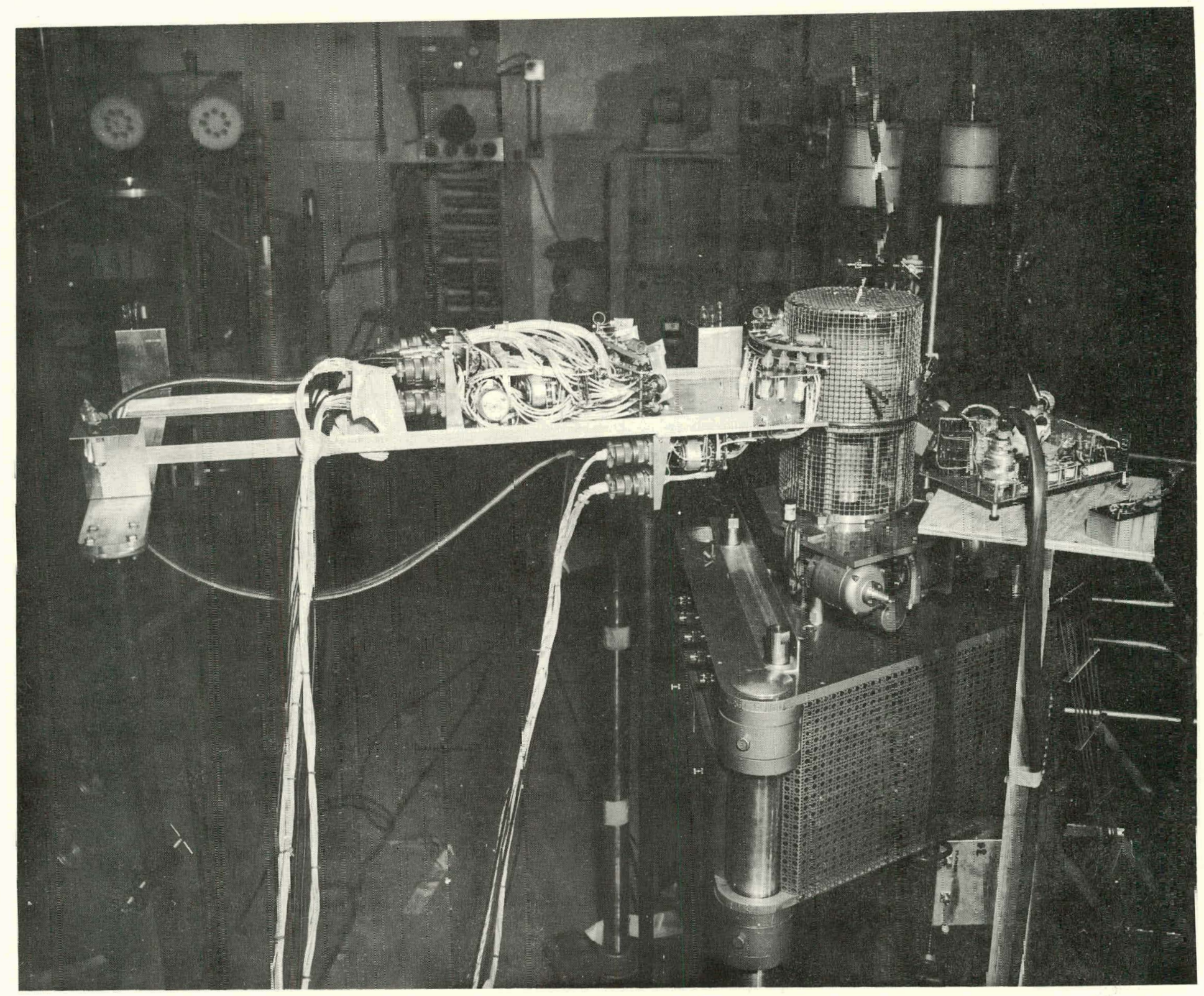

Figure 6. Typical Experimental Setup - View of Godiva II 


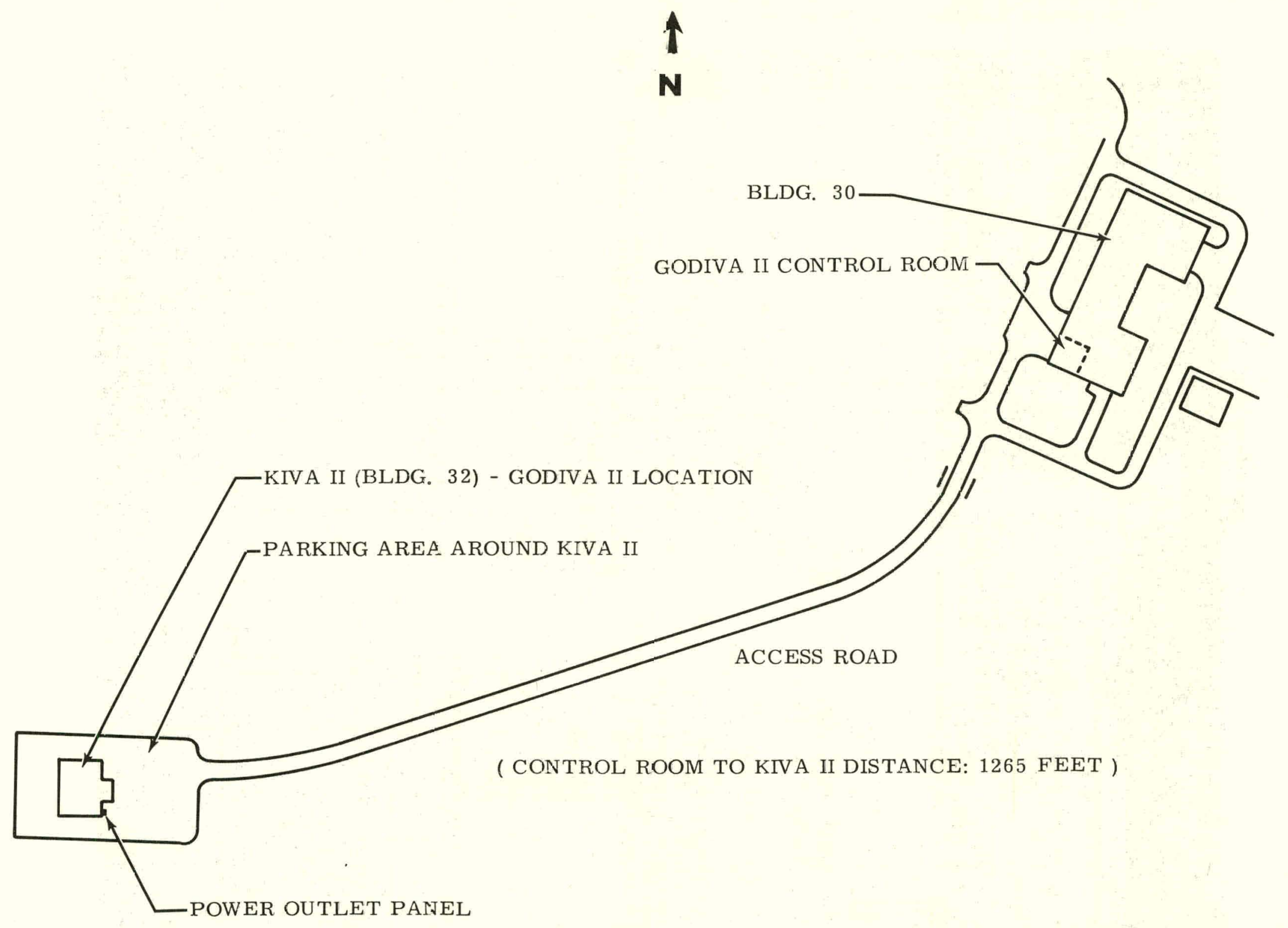

Figure 7. Kiva II and Control Room - Area Map 


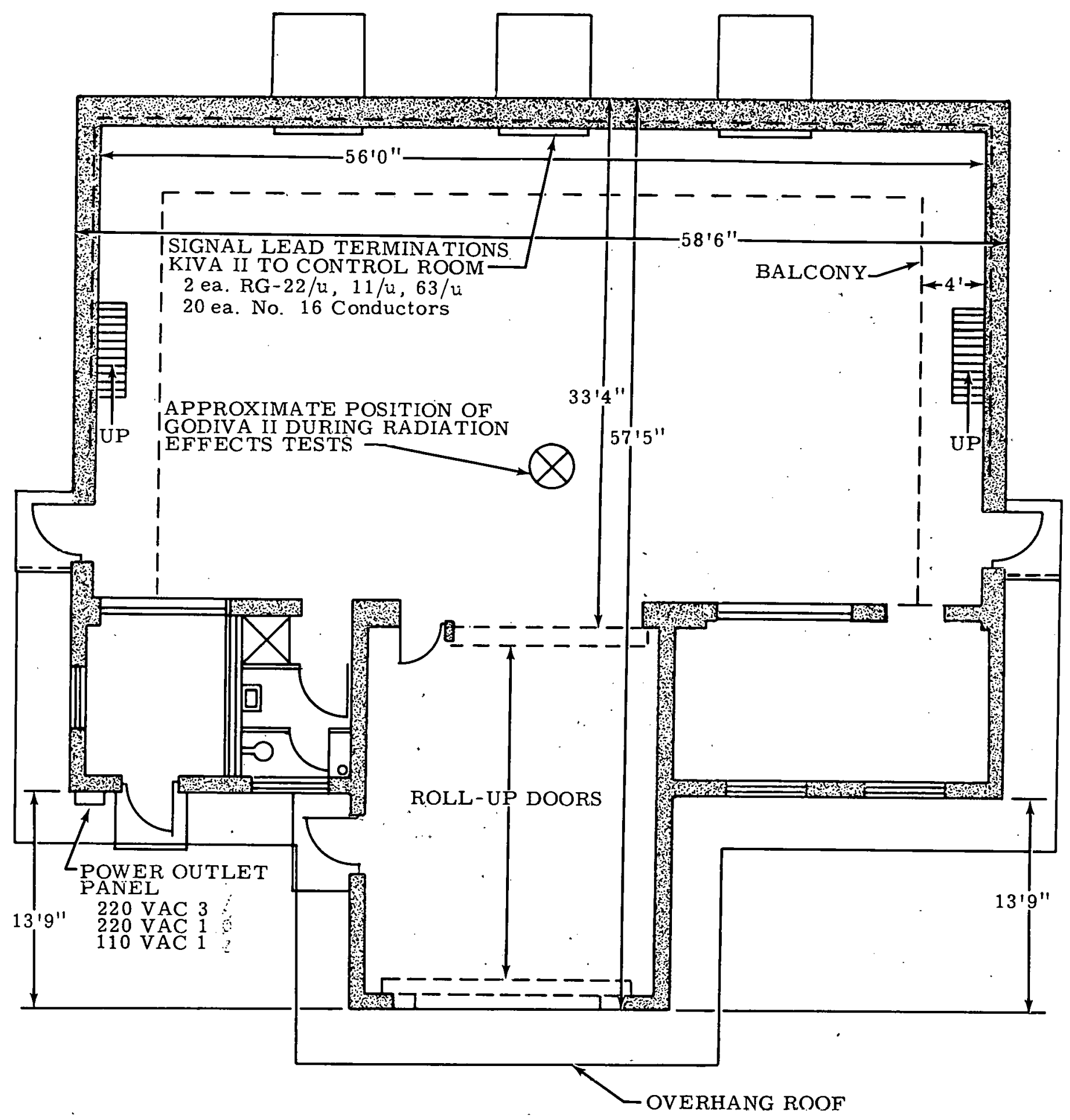

Figure 8. Kiva II - Godiva II and Facilities Layout 


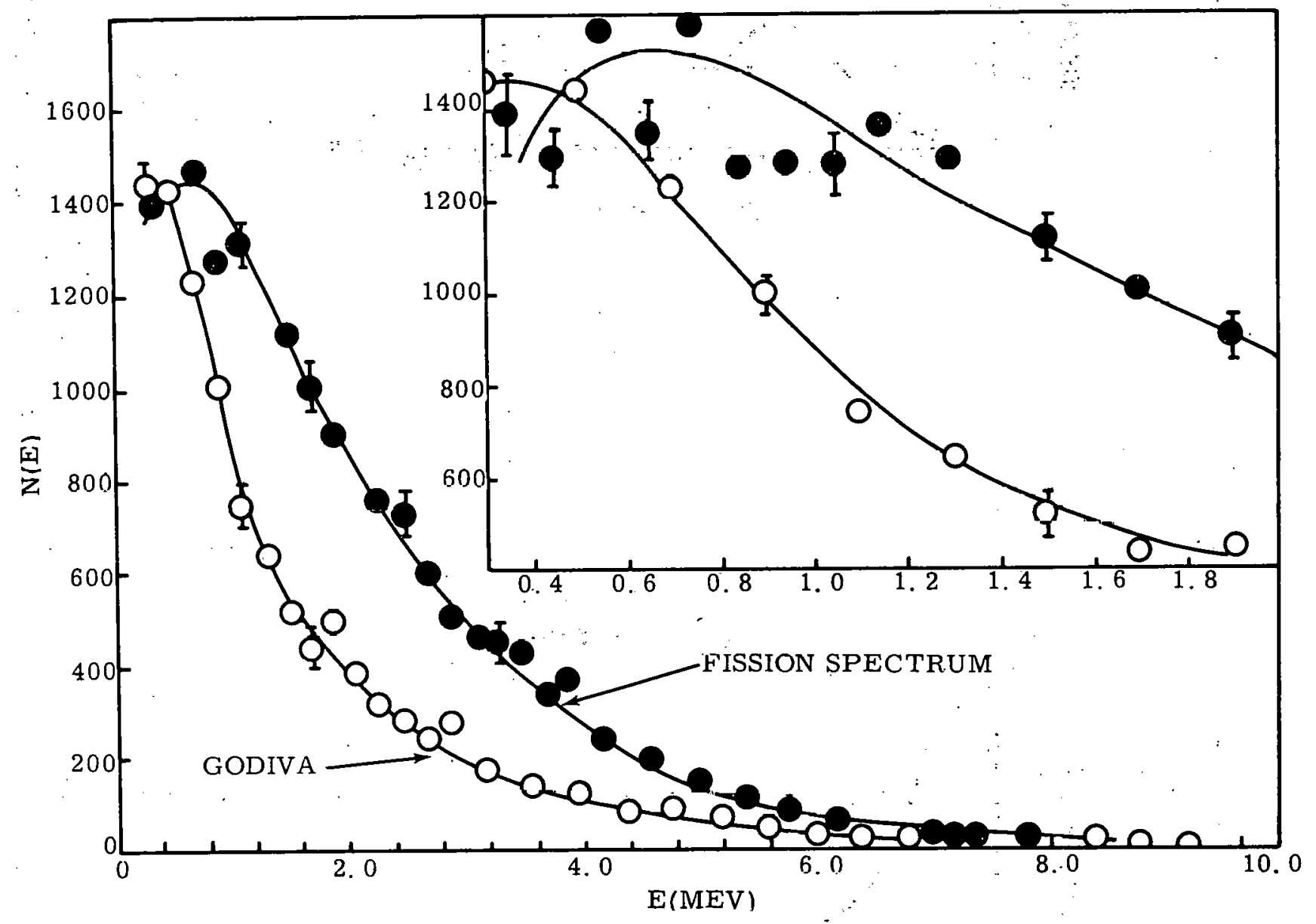

Figure 9. Spectrum Comparison - Godiva I Leakage Spectrum and $\mathrm{U}_{235}$ Fission Spectrum 


\section{A. FAST TRACE}

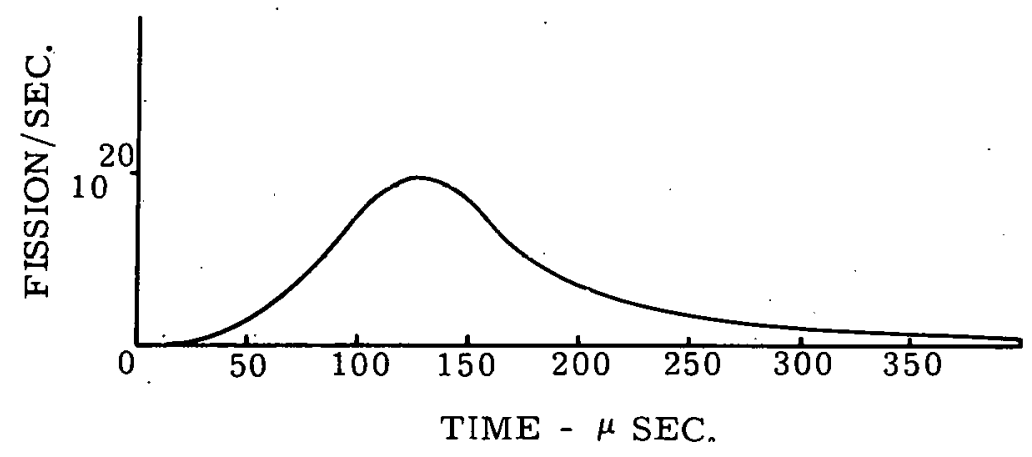

B. SLOW TRACE

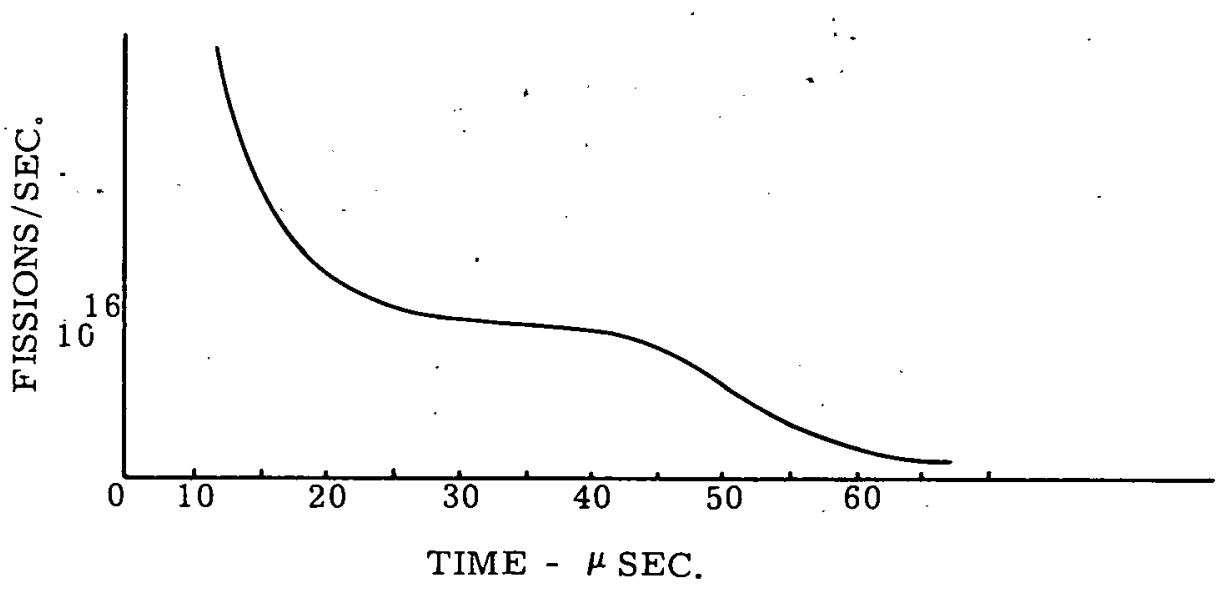

Figure 10. Typical Godiva II Fission Pulse Trace 